\title{
Generations X, Y, Z and their Perception of E-Government Services: Case of Turkey
}

\author{
Selva Ersoz ${ }^{1 *}$ \\ (iD) 0000-0001-7650-2144
}

\author{
Emel Demir Askeroğlu 2 \\ (iD) 0000-0003-3953-5734 \\ ${ }^{1}$ Istanbul Sehir University, TURKEY \\ ${ }^{2}$ Tekirdag Namik Kemal University, TURKEY \\ *Corresponding author: selvaersoz@sehir.edu.tr
}

Citation: Ersoz, S., \& Demir Askeroğlu, E. (2020). Generations X, Y, Z and their Perception of E-Government Services: Case of Turkey. Online Journal of Communication and Media Technologies, 10(1), e202002. https://doi.org/10.29333/ojcmt/6428

ARTICLE INFO

Received: 30 Sep 2019

Accepted: 3 Dec 2019

Published: 17 Dec 2019

\section{ABSTRACT}

Technological developments have transformed the forms of communication that can have a major impact on the social structure. All these technological developments cause fundamental changes in the way of life of the individuals and there are serious changes in both the ways of interpreting life and personality structures. The primary aim of this study is to examine the perceptions of online government services amongst different generations. The research of this study was carried out on the perception of e-government services with a questionnaire applied to the $X, Y, Z$ generations to measure the similarities and differences in their understanding of these services. As a result of the research, individual typologies formed by the digital use of governmental services, which are called pre-techno individuals, techno individuals and posttechno individuals and the characteristics of these generations in terms of e-government services usage are revealed.

Keywords: generations, e-government services, digital governance

\section{INTRODUCTION}

At the dawn of the third millennium and in the global scale, societies live the Internet revolution engendered by the fusion of computers, satellites and fiber optics. The communication is henceforth competed by a horizontal communication. Every individual can become its own transmitter and be able to communicate directly at real time and at any time with the other interlocutors. The politics and governance are no exception to this. The political parties, government agencies of the countries, other groups and the individuals use more and more Internet to spread their messages among others. At the same time, they establish web pages which supply a variety of tools such as political documents, interactive equipment and links of talk. With the growth of the ICT enabled devices, more activities are driven on-line. The ever developing arrival of digital technologies has created enormous opportunities for new forms of government-citizen communication. Yet one of the aspects of these developments is very promising in terms of enhancing citizen engagement in decision making processes, thus to have a better understanding of political representation, transparency and participation. While on the other hand, enabling advanced engagement with the use of ICT devices might be challenging. Since e-government has different objectives such as information, consultation and decision making or participation (Freeman \& Quirke, 2013; UNPAN, 2016), not all the time the main focus of e-government covers citizen engagement. In the current situation, countries are trying to realize egovernment with the purpose of advancing government management systems and delivering superior services to the citizens. According to United Nations e-government survey 2016, "90 countries now offer one or more single entry portal on public information or online services, or both and 148 countries provide at least one form of online transactional services". This information from the survey shows us the rise in 
countries' efforts in the matter of providing online information via e-government channels. Citizens, who are using e-government for information about the services, might still have difficulties in engaging with public agencies. This might be due to the lack of necessary applications that involve citizens in decision making processes or might be the choice of citizens who only search for information for a goal-directed purpose. Yet different generation groups, because of age differences, have further difficulties in understanding these applications.

A number of studies have explored the contribution of web sites and social media channels to citizen engagement at the municipal level (Agostino \& Arnaboldi, 2016; Firmstone \& Coleman, 2015; Lidén \& Larsson, 2016) while some other studies focus on citizen engagement in e-government services (Haider, Shuwen, \& Hyder, 2014; Kang \& Gearhart, 2010; Suh, 2005). Nevertheless, the efficiency of e-government efforts to the contribution of citizen engagement is approached with some questions. Trechselet al. (2003) noted down that "e-access is by far the most dominant e-technique being pursed while e-consultation and e-forums are noticeably lagging". This remarked us that the use of websites for information distribution purposes used commonly while the use of ICT's to empower rich forms of engagement and participation were at the beginning phases for relatively early stages of e-government back in 2003 . The primary aim of this study is to examine the perceptions of online government information amongst different generations. Consequently, the paper intends to investigate the realities about the engagement possibilities of e-government services for citizens for the case of Turkey. The research of this study was carried out on the perception of e-government services with a questionnaire applied to the $X, Y, Z$ generations to measure the similarities and differences in their understanding of these services. As a result of the research, individual typologies formed by the digital use of governmental services, which are called pre-techno individuals, techno individuals and post-techno individuals and the characteristics of these generations in terms of e-government services usage are revealed.

\section{E-GOVERNMENT AND E-FORM OF CITIZEN PARTICIPATION}

E-government is a broad term for web-based services of state and local government. In a more narrow sense, e-government is the short version of electronic government and involves the use of electronic communication devices such as computers, mobile phones and the Internet to deliver public services to citizens.

There has been great amount of studies emphasizing the definition, historical development and stages of e-government studies (Alshehri \& Drew, 2010; Haller, Li, \& Mossberger, 2011; Holzer \& Manoharan). Even though the definitions of e-government may differ in various sources, what is common in these definitions is the use of information technology for a better distribution of government services to citizens, businesses, and other government agencies.

For the primary study aim of this paper, we would like to refer to the definition of e-government in international organizations' researches such as OECD, World Bank and European Commission. Those researches cover many countries situation in terms of e-government in different aspects.

\begin{tabular}{ll}
\hline Definitions of e-government & Source \\
\hline Definition & \\
\hline Use by government agencies of information technologies (such as Wide Area Networks, the Internet, and \\
mobile computing) that have the ability to transform relations with citizens, businesses and other arms \\
of government. \\
$\begin{array}{l}\text { These technologies can serve a variety of different ends: better delivery of government services to } \\
\text { citizens, improved interactions with business and industry, citizen empowerment through access to }\end{array}$ \\
$\begin{array}{ll}\text { information, or more efficient government management. The resulting benefits can be less corruption, } \\
\text { increased transparency, greater convenience, revenue growth, and/ or cost reductions. }\end{array}$ \\
$\begin{array}{ll}\text { Use of new information and communication technologies (ICTs) by governments as applied to the full } \\
\text { range of government functions. In particular, the networking potential offered by the Internet and }\end{array}$ & OECD (2009) \\
$\begin{array}{l}\text { related technologies has the potential to transform the structures and operation of government. } \\
\text { E-government is about using the tools and systems made possible by information and communication }\end{array}$ & European Commission \\
technologies to provide better public services to citizens and businesses & (EC, 2011)
\end{tabular}

Source: Partnership on Measuring ICT for Development and the United Nations Economic Commission for Africa (2012), “Framework for a set of e-government core indicators" 
For larger scale researches, it would be effective to categorize e-government web sites according to their types and functions. International Telecommunication Union, the leading United Nations agency for information and communication, on its e-government report made a distinction among the various egovernment applications which was listed as national entry points, citizen or business-centric portals, ministry websites and provincial, local, and municipal websites (infoDev/World Bank, 2009). Based on these categorizations, we found it useful to mention two large scale ongoing projects since 2003.

One of these projects has been held by United Nations Public Administration Network on e-government. E-government is defined by United Nations Public Administration Network, UNPAN, as "utilizing the Internet and the world-wide-web for delivering government information and services to citizens" (UNPAN, 2016). UNPAN has been conducting bi-annual e-government surveys since 2003, focusing on e-government readiness of the member states. In other terms, UNPAN's e-government surveys are based on a quantitative composite index of e-government readiness constructed on website assessment and trying to measure "how willing and ready are the government around the world in employing the vast opportunities offered by e government to improve the access, and quality, of basic economic and social services to the people and involve them in public policy making via e participation" (UN Report, 2004).

E-government surveys of UNPAN measures countries' e-government services according to web presence model starting from stage 1 emerging presence to stage 5 networked presence. Examples vary from the presence of an official website, a national portal or an official home page to an integrated network of public agencies for the provision of information, knowledge and services. Apart from the e-government surveys of UNPAN, another continuous project entitled Digital Governance in Municipalities Worldwide Survey has been conducting in collaboration with E-Governance Institute at Rutgers University-Newark (Holzer \& Manoharan). Within this project, evaluation of websites of municipalities in terms of digital governance has been analyzed and ranked the cities on a global scale according to privacy/security, usability, and content of websites, the type of online services currently being offered, and citizen engagement and participation through websites of municipal governments. This ongoing survey on digital governance in municipality scale takes citizen engagement as a criterion and analyzed the situation in different municipalities worldwide in terms of social and citizen engagement.

Citizen engagement and citizen participation are two core elements to be mentioned in order to talk about participatory e-government. These concepts are the important dimensions of e-government that relates the effects of ICT's between government-citizens relations. Yet the term e-participation is missing an inclusionary definition and the connection between e-participation and citizen engagement are subject to diverse researches, it would be more appropriate to define these terms according to UN and OECD's large scale projects' definitions. E-participation index developed by UN has classified the term under three sections which are e-information, e-participation and e-decision making. Similarly OECD, without a specific index, has defined three categories to enhance the relations between citizens and governments including information, consultation and active participation (OECD Report, 2007). Both classifications suggest various ways in which e-government may contribute in the transformation of governance, not only through service delivery but also through more informed and engaged citizenship. E-government initiatives can increase participation in the processes of government through information and interactive services, and by linking people across geographic boundaries. Social media tools as well as mobile applications of e-government services provide opportunities and challenges for governments to include stakeholders in dynamic policy development, service design, co-production and feedback processes.

\section{E-GOVERNMENT IN TURKEY}

In looking at the Internet's brief history in Turkey, the country has got public Internet access since 1993. The first available connections were dialup. Cable Internet has been available since 1998 and ADSL since 2003. For today's statistics, according to Turkish Statistical Institute study of ICT usage in households, 8 out of 10 households have Internet access and Internet usage of individuals was $61.2 \%$ by August 2016. As of August 2016 social networks took first place among the activities for Turkish Internet users, while $61.8 \%$ of Internet users used e-government services (Sæbø, Rose, and Skiftenes Flak, 2008). These statistics are showing us the 
growing interest of Turkish citizens are not only concentrated on Internet use in general but on e-government services in particular.

Development of e-government in Turkey started in early 1990's with the purpose of increasing Turkey's competitiveness focusing on innovation, science and technology and strengthening ICT capacities and capabilities in Turkey (OECD Report, 2007). Starting from 2002, the process of modernization of public administration by implementing e-government as a tool has started. By February 2016, 216 public institutions provide 1.411 e-services to 26.546 .787 registered users of the e-government gateway (portal) "https://www.turkiye.gov.tr/" that is the single contact point for many public institutions' e-services besides the institutions own website (Turkish Statistical Institute, 2016). Since 2011, Ministry of Transportation, Maritime Affairs and Communications is tasked with the coordination and supervision of the objectives and strategies of the relevant public authorities such as Ministry of Development and Information Society Department in the field of e-government.

Effective use of e-government can expand the efficiency and success of the public sector and links between government agencies. E-government development in countries is at different stages. Developed economies are relatively advanced in their use of ICT for advanced functioning of the public sector and service delivery.

Methodologies range from country-level surveys of government organizations to highly complex webbased surveys. On the global stage, UN's e-Government Survey 2016 that scores Turkey high on the eparticipation index which measures three-level model of participation that includes e-information, econsultation and e-decision-making. Turkey's e-participation index score is 0.6271 and is positioned on the $60^{\text {th }}$ out of 193 countries with $73.5 \%$ of readiness for e-information, $68.4 \%$ of readiness for e-consultation and $0 \%$ of readiness for e-decision making stages and overall $63.3 \%$ of readiness for e-participation. Another ranking criterion of the survey is on online service index according to which Turkey scores amongst the high level countries with the position of 68 (UNPAN report, 2016).

United Nations e-Government Survey is the most comprehensive survey that is being done in this domain. The important matter of this survey is that it covers 193 countries worldwide and is giving all the measurements according to regions as well. Europe wise, Turkey has been also analyzed under the ongoing projects of European Commission on e-government benchmarking of member states of European Union and Iceland, Montenegro, Norway, Serbia, Switzerland and Turkey for a number of years (Joinup Europa, 2016). The country performance is evaluated in terms of penetration and digitization. There has been noted two important outcomes of the project about Turkey. One of these was the country's progressive trend both on penetration and digitization within the years and the second was Turkey's high mobile users' profile but the lack of mobile friendly versions of public services. This second has been a general problem in all countries analyzed where only 1 in 3 public websites is easy to read and allow navigation on a mobile device (Joinup Europa, 2016).

\section{E-GOVERNMENT AND E-CITIZEN RELATIONS: THE CASE OF TURKEY}

E-Government services have been established to fasten the expansion of government in terms of quality, cost and distribution. Technology driven developments in every aspect of the social life, including the developments in e-government issues, continue to affect the life of citizens. Nevertheless, not all the citizens' reaction about managing technology and digital improvements is the same. This could be explained by the ability of technology usage amongst different generations. There are no definite dates for the starting and ending of generations according to different sources, yet generational differences, especially the differences between generations described as the Baby Boom Generation, Generation X, Y and Z are widely discussed in the popular press as well as in some scholarly publications.

As shown in Table 1, Reeves and Oh (2008, p. 296) briefly summarized the generational differences according to different scholars. The uncertainty about the dates and the denomination of the generations is quite visible. For example, some experts indicate that Generation Y workers were born in 1978 (Martin \& Tulgan, 2002), while others (Howe \& Strauss, 2000) have selected a starting date of 1982. 
Table 1. Generational Labels and Dates Reported in Different Sources

\begin{tabular}{|c|c|c|c|c|c|}
\hline Source & & & Labels & & \\
\hline $\begin{array}{l}\text { Howe and } \\
\text { Strauss (2000) }\end{array}$ & $\begin{array}{l}\text { Silent Generation } \\
\quad(1925-1943)\end{array}$ & $\begin{array}{l}\text { Boom Generation } \\
(1943-1960)\end{array}$ & $\begin{array}{c}\text { 13th Generation } \\
(1961-1981)\end{array}$ & Millennial Generation (1982-2000) & - \\
\hline $\begin{array}{l}\text { Lancaster and } \\
\text { Stillman (2002) }\end{array}$ & $\begin{array}{l}\text { Traditionalists } \\
\text { (1900-1945) }\end{array}$ & $\begin{array}{l}\text { Baby Boomers (1946- } \\
\text { 1964) }\end{array}$ & $\begin{array}{l}\text { Generation Xers } \\
(1965-1980)\end{array}$ & $\begin{array}{c}\text { Millennial Generation; Echo Boomer; } \\
\text { Generation Y; Baby Busters; } \\
\text { Generation Next (1981-1999) }\end{array}$ & - \\
\hline $\begin{array}{l}\text { Martin and } \\
\text { Tulgan (2002) }\end{array}$ & $\begin{array}{c}\text { Silent Generation } \\
(1925-1942)\end{array}$ & $\begin{array}{c}\text { Baby Boomers (1946- } \\
\text { 1960) }\end{array}$ & $\begin{array}{c}\text { Generation X } \\
(1965-1977)\end{array}$ & Millennials (1978-2000) & - \\
\hline $\begin{array}{l}\text { Oblinger and } \\
\text { Oblinger (2005) } \\
\end{array}$ & Matures (<1946) & $\begin{array}{c}\text { Baby Boomers (1947- } \\
\text { 1964) }\end{array}$ & $\begin{array}{c}\text { Gen-Xers (1965- } \\
1980)\end{array}$ & $\begin{array}{c}\text { Gen-Y; NetGen; Millennials (1981- } \\
\text { 1995) }\end{array}$ & $\begin{array}{l}\text { Post-Millennials } \\
\text { (1995-present) } \\
\end{array}$ \\
\hline Tapscott (1998) & - & $\begin{array}{c}\text { Baby Boom Generation } \\
(1946-1964)\end{array}$ & $\begin{array}{c}\text { Generation X } \\
(1965-1975) \\
\end{array}$ & Digital Generation (1976-2000) & - \\
\hline $\begin{array}{l}\text { Zemke et al. } \\
(2000)\end{array}$ & $\begin{array}{c}\text { Veterans (1922- } \\
1943)\end{array}$ & $\begin{array}{c}\text { Baby Boomers (1943- } \\
\text { 1960) }\end{array}$ & $\begin{array}{c}\text { Gen-Xers (1960- } \\
1980) \\
\end{array}$ & Nexters (1980-1999) & - \\
\hline
\end{tabular}

Source: (Reeves \& Oh, 2008, p. 296)

Table 2. Adaptation of Age Groups according to generations

\begin{tabular}{cccc}
\hline Generations & Age Group & Population & \% \\
\hline$X$ & $57-40$ & 22603338 & 22.63 \\
\hline$Y$ & $39-20$ & 25416508 & 31.86 \\
\hline$Z$ & $19-17$ & 5623319 & \\
\hline
\end{tabular}

Source: (Turkish Statistical Institute Report, 2017)

Table 3. World Values Survey Wave 6: 2010-2014, Important in life: Politics -Turkey

\begin{tabular}{|c|c|c|c|c|}
\hline & TOTAL & & Age & \\
\hline & & Up to 29 & $30-49$ & 50 and more \\
\hline Very important & 16.1 & 14.3 & 15.5 & 19.2 \\
\hline Rather important & 31.3 & 35.9 & 30.5 & 28 \\
\hline Not very important & 32.3 & 33.8 & 33 & 29.3 \\
\hline Not at all important & 19.2 & 15.3 & 19.5 & 22.7 \\
\hline No answer & 0.2 & 0.2 & 0.3 & 0 \\
\hline Don't know & 0.9 & 0.5 & 1.2 & 0.9 \\
\hline$(\mathrm{N})$ & 1.605 & 450 & 735 & 420 \\
\hline
\end{tabular}

Source: World Values Survey

On the other hand, the generation studies may vary from one society to another, especially if we count on life perceptions and expectations of these different generation groups. For this reason we have divided the so defined as millennial generation into two different groups as $Y$ and $Z$. For the $Z$ generation we have only considered the age groups 17-19 as the research part of this study would be concentrating on perception of e-government services. Normally $Z$ generation consists of wider age groups but given the research aim, we have selected 17-19 ages for $Z$ generation due to the fact that only those age groups from $Z$ generation might consider using e-government services.

Since our research would be consisting of Turkish citizens, we referred to Turkish Statistical Institute's population data from 2016 and adopted the generation studies from the literature to Turkish population.

According to the address-based population registration data of TÜiK in 2016, population of generations were determined to be 5,6 million for Generation Z (7.30\%), 25.4 million for Generation Y (31.86\%), 22 million (22.63\%) for Generation X.

The focus of this study is on the three generations $(X, Y, Z)$, because members of these three generations considered to be using e-governmental services more than other generation groups. For the purposes of this study, instead of mentioning the overall differences of these three generations, it would be more significant to emphasize the attitudes about politics and use of technology. According to World Values Survey, the importance given to politics by Turkish citizens of different age groups can be seen on Table 3 .

A World Value's survey shows that $16 \%$ of the population finds politics very important in life; $31.3 \%$ finds it rather important in life and $19.2 \%$ finds politics not important at all in life. This clearly demonstrates that there is divided interested in politics; while half of the population surveyed found it relatively important, the other half did not. Nonetheless, this survey only has measured the interest in politics but excludes the perception of e-government services. 
Another aspect of generational difference for this study, is related to use of technology. According to Pew Research Center's report on generations, millennial generations ( $Y, Z$ ) have a positive attitude towards technological devices of any sort while generation $X$ does not. Although elder generation groups own the technological devices such as mobile phone, tablets and laptops, the usage aim and objective usually orients to less complicated activities in those older generations. Consequently, this can be interpreted as a divide not in terms of possession the devices but in terms of usage habits and knowledge (Pew Research Center, 2010).

A recently published press release of Turkish Statistical Institute dated August 2017 gave us some additional information about the practice of e-government services by citizens: "During the twelve months (April 2016-March 2017), 42.4\% of Internet users among the individuals aged 16-74 interacted with public authorities over the Internet for private purposes. This proportion was 36.7\% for the period of April 2015March 2016. Obtaining information from public authorities' web sites was at the first rank with 37.6\%" (Turkish Statistical Institute, 2017).

\section{Method of the Research}

A questionnaire consisting of 18 questions was conducted as data collection method in this research. The use of the e-government system is addressed and the benefits and confidence gained in this use are addressed. The question types used in the questionnaires are multiple choice questions, 5 questions Likert, approval questions as linear scale question. In the confirmation questions, there are more than one choice of option. In the multiple choice questions, the 'other' option was added to the questionnaire using the openended question type. Using the 5-point Likert Scale, participants were asked to choose between "absolutely disagree", "disagree", "undecided", "agree", "strongly agree".

It is summarized with table and graphical methods of descriptive statistical methods, then analyzed with procedural statistical methods and further analyzes are made. In addition to the Internet environment, individual surveys have provided the deepening of the work in the qualitative aspect, and comments on numerical analysis have been made.

\section{Assumptions and Limitations of the Research}

A total of 355 people has been reached in this study. These individuals, chosen by random sample method, adequately represent the population. These quantities have been tested with the KMO Barlett test. The scales used in this study were found to be in accordance with factor analysis. The two-stage questionnaire was consisted of 150 participants in the online survey and 205 participants in the individual interviews.

Responses to research questions are rational. These responses were analyzed by Mann Whitney and Kruskal Wallis methods. Limitations of the research are also listed below:

- The population in this research was identified as Internet users.

- In an individual survey study, among the people born between 1960-1977, 1978-1997, 1998-2000, individuals who actively use the Internet were selected.

- The online part of the research was done by using the snowball sampling method over the social media users.

\section{Collection and Analysis of data}

After the conceptual part of the work was created by literature review, 18-question questionnaire form was created by Google Forms for the research part of the study. The obtained data were obtained with SPSS 23 program and the 95\% confidence level was used. Nonparametric test techniques Mann Whitney and Kruskal Wallis were used in the study. Mann Whitney is a test technique used to compare two independent groups in terms of a quantitative variable, Kruskal Wallis' independent group k $(k>2)$ in terms of a quantitative variable. The nonparametric Kruskal-Wallis test is used to determine whether 3 or more groups / samples come from the same phase for a number of $\mathrm{K}$ groups. The Kruskal-Wallis test is used when the assumptions required for one-factor variance analysis that is parametric to this test cannot be met. The hypotheses of the research are listed below:

H1a: I see the e-government services as a system to facilitate bureaucratic operations

$\mathrm{H} 1 \mathrm{~b}$ : Actively use the e-government services 
Table 4. Information for E-Government Use

\begin{tabular}{|c|c|c|c|}
\hline & & $\mathbf{n}$ & $\%$ \\
\hline \multirow{2}{*}{ Do you have an e-government system use password? } & Yes & 333 & 82.2 \\
\hline & No & 72 & 17.8 \\
\hline \multirow{2}{*}{$\begin{array}{l}\text { Purpose of using the e-government system; electronic } \\
\text { payroll }\end{array}$} & Yes & 60 & 14.8 \\
\hline & No & 346 & 85.2 \\
\hline \multirow{2}{*}{$\begin{array}{l}\text { Purpose of using the e-government system; judicial } \\
\text { proceedings }\end{array}$} & Yes & 77 & 19.0 \\
\hline & No & 329 & 81.0 \\
\hline \multirow{2}{*}{ Purpose of using the e-government system; debt inquiry } & Yes & 108 & 26.6 \\
\hline & No & 298 & 73.4 \\
\hline \multirow{2}{*}{$\begin{array}{l}\text { Purpose of using the e-government system; getting } \\
\text { information }\end{array}$} & Yes & 277 & 68.2 \\
\hline & No & 129 & 31.8 \\
\hline \multirow{2}{*}{ Purpose of using the e-government system; other } & Yes & 40 & 9.9 \\
\hline & No & 366 & 90.1 \\
\hline
\end{tabular}

Table 5. Relation Analysis of Generation Groups' Level of Involvement with Scale Exceptions

\begin{tabular}{|c|c|c|c|c|}
\hline Generation & & & $\begin{array}{l}\text { I see the e-government system } \\
\text { as a system to facilitate } \\
\text { bureaucratic operations }\end{array}$ & $\begin{array}{l}\text { Through e-government system, I am } \\
\text { notified to the official institutions } \\
\text { of desire, complaints and requests }\end{array}$ \\
\hline \multirow{6}{*}{ 1960-1977 } & \multirow{3}{*}{$\begin{array}{l}\text { Actively use the e-government } \\
\text { system }\end{array}$} & $\mathrm{r}$ & -.064 & .002 \\
\hline & & $\mathrm{p}$ & .458 & .982 \\
\hline & & $\mathrm{n}$ & 135 & 135 \\
\hline & \multirow{3}{*}{$\begin{array}{l}\text { I see the e-government system as } \\
\text { a system to facilitate bureaucratic } \\
\text { operations }\end{array}$} & $r$ & 1 & $.396^{* *}$ \\
\hline & & $\mathrm{p}$ & & .000 \\
\hline & & $\mathrm{n}$ & 135 & 135 \\
\hline \multirow{6}{*}{ 1978-1997 } & \multirow{3}{*}{$\begin{array}{l}\text { Actively use the e-government } \\
\text { system }\end{array}$} & $r$ & .149 & .119 \\
\hline & & $\mathrm{p}$ & .085 & .167 \\
\hline & & $\mathrm{n}$ & 135 & 135 \\
\hline & \multirow{3}{*}{$\begin{array}{l}\text { I see the e-government system as } \\
\text { a system to facilitate bureaucratic } \\
\text { operations }\end{array}$} & $r$ & 1 & $.319^{* *}$ \\
\hline & & $\mathrm{p}$ & & .000 \\
\hline & & $\mathrm{n}$ & 135 & 135 \\
\hline \multirow{6}{*}{$1998-2000$} & \multirow{3}{*}{$\begin{array}{l}\text { Actively use the e-government } \\
\text { system }\end{array}$} & $r$ & -.022 & -.103 \\
\hline & & $\mathrm{p}$ & .796 & .233 \\
\hline & & $\mathrm{n}$ & 135 & 135 \\
\hline & \multirow{3}{*}{$\begin{array}{l}\text { I see the e-government system as } \\
\text { a system to facilitate bureaucratic } \\
\text { operations }\end{array}$} & $r$ & 1 & $.304^{\star \star}$ \\
\hline & & $p$ & & .000 \\
\hline & & $\mathrm{n}$ & 135 & 135 \\
\hline
\end{tabular}

H1c: Using e-government services and notifying official institutions of complaints and requests

Based on the above hypotheses, generation typology has been realized according to the obtained data. According to the rate of influence of the generations from the digital culture (by analyzing with the questions), the characteristics of the individuals and typologies are formed.

Table 4 shows the e-government usage information of the participants. The majority of participants have e-government ciphers (82.2\%). The purpose of e-government use; the ratio of those who have payroll is $14.8 \%$; the proportion of those with judicial proceedings is $19.0 \%$; the proportion of those who have debt questioning is $26.6 \%$; the rate of acquiring information is $68.2 \%$; the rate of those with other causes is $9.9 \%$.

The results of the relationship test of the participation level and generation groups in scale expressions are seen in the above Table 5.

\section{Generation of 1960-1977}

There is a positive and weak relationship between the level of participation in the expression "I see the egovernment services as a system facilitating bureaucratic operations" and the level of participation in the expression of "complaints and requests to inform official institutions via the e-government system".

\section{Generation of 1978-1997}

There is a positive and weak relationship between the level of participation in the expression "I see the egovernment services as a system facilitating bureaucratic operations" and the level of participation in the expression of "complaints and requests to inform official institutions via the e-government system". 
Table 6. Comparison of Generation Groups in Terms of Scale Expressions Participation Level

\begin{tabular}{|c|c|c|c|c|c|}
\hline What is your age range? & & $\mathbf{n}$ & Rank average & $x^{2}$ & $\mathbf{p}$ \\
\hline \multirow{3}{*}{ Actively use the e-government system } & 1960-1977 & 135 & 201.90 & \multirow{3}{*}{6.302} & \multirow{3}{*}{$0.043 *$} \\
\hline & $1978-1997$ & 135 & 220.97 & & \\
\hline & $1998-2000$ & 135 & 186.13 & & \\
\hline \multirow{3}{*}{$\begin{array}{l}\text { I see the e-government system as a system to facilitate bureaucratic } \\
\text { operations }\end{array}$} & $1960-1977$ & 135 & 194.93 & \multirow{3}{*}{1.026} & \multirow{3}{*}{0.599} \\
\hline & 1978-1997 & 135 & 207.06 & & \\
\hline & $1998-2000$ & 135 & 207.01 & & \\
\hline \multirow{3}{*}{$\begin{array}{l}\text { Through e-government system, I am notified to the official } \\
\text { institutions of desire, complaints and requests }\end{array}$} & $1960-1977$ & 135 & 224.99 & \multirow{3}{*}{8.657} & \multirow{3}{*}{$0.013 *$} \\
\hline & 1978-1997 & 135 & 197.94 & & \\
\hline & $1998-2000$ & 135 & 186.07 & & \\
\hline
\end{tabular}

Table 7. Comparison of Gender Groups in Terms of Scale Expressions Participation Level Between 1960-1977

\begin{tabular}{|c|c|c|c|c|c|}
\hline Gender & & $\mathbf{n}$ & Rank average & $\mathbf{U}$ & $\mathbf{p}$ \\
\hline \multirow{2}{*}{ Actively use the e-government system } & Female & 62 & 62.02 & \multirow{2}{*}{1892.0} & \multirow{2}{*}{0.092} \\
\hline & Male & 73 & 73.08 & & \\
\hline \multirow{2}{*}{$\begin{array}{l}\text { I see the e-government system as a system to facilitate bureaucratic } \\
\text { operations }\end{array}$} & Female & 62 & 66.35 & \multirow{2}{*}{2161.0} & \multirow{2}{*}{0.643} \\
\hline & Male & 73 & 69.40 & & \\
\hline \multirow{2}{*}{$\begin{array}{l}\text { Through e-government system, I am notified to the official institutions } \\
\text { of desire, complaints and requests }\end{array}$} & Female & 62 & 75.06 & \multirow{2}{*}{1825.5} & \multirow{2}{*}{0.047 * } \\
\hline & Male & 73 & 62.01 & & \\
\hline
\end{tabular}

Table 8. Comparison of Gender Groups in 1978-1997 in terms of Scale Grades Participation Level

\begin{tabular}{|c|c|c|c|c|c|}
\hline Gender & & $\mathbf{n}$ & Rank average & $\mathbf{U}$ & $\mathbf{p}$ \\
\hline \multirow{2}{*}{ Actively use the e-government system } & Female & 61 & 63.03 & \multirow{2}{*}{1954.0} & \multirow{2}{*}{0.167} \\
\hline & Male & 74 & 72.09 & & \\
\hline \multirow{2}{*}{$\begin{array}{l}\text { I see the e-government system as a system to facilitate bureaucratic } \\
\text { operations }\end{array}$} & Female & 61 & 73.25 & \multirow{2}{*}{1937.0} & \multirow{2}{*}{0.142} \\
\hline & Male & 74 & 63.68 & & \\
\hline \multirow{2}{*}{$\begin{array}{l}\text { Through e-government system, I am notified to the official institutions } \\
\text { of desire, complaints and requests }\end{array}$} & Female & 61 & 65.46 & \multirow{2}{*}{2102.0} & \multirow{2}{*}{0.467} \\
\hline & Male & 74 & 70.09 & & \\
\hline
\end{tabular}

Table 9. Comparison of Gender Groups in the scale of 1998-2000 in terms of Scale Grades Participation Level

\begin{tabular}{|c|c|c|c|c|c|}
\hline Gender & & $\mathbf{n}$ & Rank average & $U$ & $\mathbf{p}$ \\
\hline \multirow{2}{*}{ Actively use the e-government system } & Female & 80 & 65.18 & \multirow{2}{*}{1974.0} & \multirow{2}{*}{0.298} \\
\hline & Male & 55 & 72.11 & & \\
\hline \multirow{2}{*}{$\begin{array}{l}\text { I see the e-government system as a system to facilitate bureaucratic } \\
\text { operations }\end{array}$} & Female & 80 & 71.38 & \multirow{2}{*}{1929.5} & \multirow{2}{*}{0.210} \\
\hline & Male & 55 & 63.08 & & \\
\hline \multirow{2}{*}{$\begin{array}{l}\text { Through e-government system, I am notified to the official institutions } \\
\text { of desire, complaints and requests }\end{array}$} & Female & 80 & 69.51 & \multirow{2}{*}{2079.0} & \multirow{2}{*}{0.558} \\
\hline & Male & 55 & 65.80 & & \\
\hline
\end{tabular}

\section{Generation of 1998-2000}

"I see the e-government services as a system to facilitate bureaucratic operations" statement provokes weak positive relationship between the level of participation in the phrase "complaints, and requests to make statements to government agencies via the e-government system".

In Tables 6 and 7, there is a comparative test in terms of scale expressions participation scores among gender groups according to generations. According to Mann Whitney test for men and women in different generation groups; there is a statistically significant difference between women and men between 1960-1977 in terms of participation level in the statement "complaints and requests to inform official institutions via egovernment system" $(U=1825.5, p<0.05)$. The average score of women is 75.06 , while that of men is 62.01 . Accordingly, the level of participation of women in the expression is higher.

In Table 10, there is a comparative test in terms of scale grades participation level. According to Mann Whitney test for working status in different generation groups; there is a statistically significant difference in the level of participation in the phrase "actively use of the e-government services" among the working conditions of the 1960-1977 bourse. $(U=1001.0, p<0.05)$. The average score of those who work is 76.68 , while those who are not working are 45.84. Accordingly, those who are working have a higher level of participation in the expression. 
Online Journal of Communication and Media Technologies, 2020

Table 10. Comparing Working Status in the 1960-1977 Circle in Terms of Scale Expressions Participation Level

\begin{tabular}{|c|c|c|c|c|c|}
\hline Working status & & $\mathbf{n}$ & Rank average & U & p \\
\hline \multirow{2}{*}{ Actively use the e-government system } & Employed & 97 & 76.68 & \multirow{2}{*}{1001.0} & \multirow{2}{*}{$0.000 *$} \\
\hline & Unemployed & 38 & 45.84 & & \\
\hline \multirow{2}{*}{$\begin{array}{l}\text { I see the e-government system as a system to facilitate } \\
\text { bureaucratic operations }\end{array}$} & Employed & 97 & 69.10 & \multirow{2}{*}{1736.0} & \multirow{2}{*}{0.591} \\
\hline & Unemployed & 38 & 65.18 & & \\
\hline \multirow{2}{*}{$\begin{array}{l}\text { Through e-government system, I am notified to the official } \\
\text { institutions of desire, complaints and requests }\end{array}$} & Employed & 97 & 64.42 & \multirow{2}{*}{1495.5} & \multirow{2}{*}{0.080} \\
\hline & Unemployed & 38 & 77.14 & & \\
\hline
\end{tabular}

Table 11. Comparison of Working Status in 1978-1997 in terms of Scale Expressions Participation Level

\begin{tabular}{lccccc}
\hline \multicolumn{1}{c}{ Working status (1978-1998) } & & $\mathbf{n}$ & $\begin{array}{c}\text { Rank } \\
\text { average }\end{array}$ & U & $\mathbf{p}$ \\
\hline Actively use the e-government system & Employed & 75 & 74.45 & \multirow{2}{*}{$\mathbf{1 7 6 6 . 5}$} & \multirow{2}{*}{$\mathbf{0 . 0 2 7 *}$} \\
\cline { 2 - 4 } $\begin{array}{l}\text { I see the e-government system as a system to facilitate } \\
\text { bureaucratic operations }\end{array}$ & Unemployed & 60 & 59.94 & \\
\cline { 1 - 4 } $\begin{array}{l}\text { Through e-government system, I am notified to the official } \\
\text { institutions of desire, complaints and requests }\end{array}$ & Enployed & 75 & 67.12 & \multirow{2}{*}{$\mathbf{2 1 8 4 . 0}$} & \multirow{2}{*}{$\mathbf{0 . 7 6 2}$} \\
\hline
\end{tabular}

Table 12. Comparison of Working Status in 1998-2000 in terms of Scale Expressions Participation Level

\begin{tabular}{|c|c|c|c|c|c|}
\hline Working status (1998-2000) & & $\mathbf{n}$ & $\begin{array}{c}\text { Rank } \\
\text { average }\end{array}$ & $\mathbf{U}$ & $\mathbf{p}$ \\
\hline \multirow{2}{*}{ Actively use the e-government system } & Employed & 27 & 85.93 & \multirow{2}{*}{974.0} & \multirow{2}{*}{$0.006 *$} \\
\hline & Unemployed & 108 & 63.52 & & \\
\hline \multirow{2}{*}{$\begin{array}{l}\text { I see the e-government system as a system to facilitate } \\
\text { bureaucratic operations }\end{array}$} & Employed & 27 & 54.24 & \multirow{2}{*}{1086.5} & \multirow{2}{*}{$0.035 *$} \\
\hline & Unemployed & 108 & 71.44 & & \\
\hline \multirow{2}{*}{$\begin{array}{l}\text { Through e-government system, I am notified to the official } \\
\text { institutions of desire, complaints and requests }\end{array}$} & Employed & 27 & 50.98 & \multirow{2}{*}{998.5} & \multirow{2}{*}{$0.006 *$} \\
\hline & Unemployed & 108 & 72.25 & & \\
\hline
\end{tabular}

In Table 11, there is a comparative test in terms of score expression participation level scores among the study groups according to generation groups. According to Mann Whitney test for working status in different generation groups; there is a statistically significant difference in the level of participation level in the phrase "active use of the e-government system" among the working status of the circles between 1978-1997 (U = $1766,5, p<0,05)$. The average score of those who work is 74.45 , while those who are not working are 59.94 . Accordingly, those who are working have a higher level of participation in the expression.

There is a statistically significant difference in the level of participation in the expression of "complaints and requests to inform the official institutions via the e-government system" among the working status of the circles between 1978-1997 $(U=1806.0, p<0.05)$. The average score of those who work is 73.92 , while those who are not working are 60.60. Accordingly, those who are working have a higher level of participation in the expression.

In Table 12, there is a comparative test in terms of score expression participation level scores among the study groups according to generation groups. According to Mann Whitney test for working status in different generation groups; there is a statistically significant difference in the level of participation level in the phrase "actively use of the e-government services" between the working status of the 1998-2000 level $(U=974.0, p$ $<0.05$ ). The average score of those who are working is 85.93, while those who are not working are 63.52 . Accordingly, those who are working have a higher level of participation in the expression.

There is a statistically significant difference $(U=1086.5, p<0.05)$ in terms of participation level score in the expression of "I see the e-government system as a system facilitating bureaucratic operations" among the working status of the circles of 1998-2000. The average score of those who work is 54.24, while those who are not working are 71.44. Accordingly, those who are not working have a higher level of participation in the expression. There is a statistically significant difference $(U=1086.5, p<0.05)$ in terms of participation level score in the expression of "I see the e-government system as a system facilitating bureaucratic operations" among the working status of the circles of 1998-2000. The average score of those who work is 54.24, while those who are not working are 71.44. Accordingly, those who are not working have a higher level of participation in the expression. 
Table 13. Comparison of Educational Status Groups of 1960-1977 in terms of Scale Expression Participation Level

\begin{tabular}{|c|c|c|c|c|c|}
\hline Education Status & & $\mathbf{n}$ & rank average & $\mathbf{X} 2$ & $\mathbf{p}$ \\
\hline \multirow{6}{*}{ Actively use the e-government system } & Primary school & 19 & 35.68 & \multirow{6}{*}{25.732} & \multirow{6}{*}{$0.000 *$} \\
\hline & Middle School & 20 & 59.10 & & \\
\hline & High School & 34 & 63.47 & & \\
\hline & Vocational school & 17 & 80.59 & & \\
\hline & University & 30 & 81.83 & & \\
\hline & Graduate - PHD & 15 & 89.13 & & \\
\hline \multirow{6}{*}{$\begin{array}{l}\text { I see the e-government system as a system to } \\
\text { facilitate bureaucratic operations }\end{array}$} & Primary school & 19 & 73.58 & \multirow{6}{*}{6.802} & \multirow{6}{*}{0.236} \\
\hline & Middle School & 20 & 61.35 & & \\
\hline & High School & 34 & 73.82 & & \\
\hline & Vocational school & 17 & 81.00 & & \\
\hline & University & 30 & 56.07 & & \\
\hline & Graduate - PHD & 15 & 65.73 & & \\
\hline \multirow{6}{*}{$\begin{array}{l}\text { Through e-government system, I am notified to the } \\
\text { official institutions of desire, complaints and } \\
\text { requests }\end{array}$} & Primary school & 19 & 67.47 & \multirow{6}{*}{4.453} & \multirow{6}{*}{0.486} \\
\hline & Middle School & 20 & 63.40 & & \\
\hline & High School & 34 & 76.75 & & \\
\hline & Vocational school & 17 & 65.97 & & \\
\hline & University & 30 & 58.88 & & \\
\hline & Graduate - PHD & 15 & 75.50 & & \\
\hline
\end{tabular}

Table 14. Comparison of Educational Status Groups of 1978-1997 in terms of Scale Expression Participation Level

\begin{tabular}{|c|c|c|c|c|c|}
\hline Education Status & & $\mathbf{n}$ & rank average & $\mathrm{X} 2$ & $\mathbf{p}$ \\
\hline \multirow{4}{*}{ Actively use the e-government system } & High school and under & 23 & 64.41 & \multirow{4}{*}{6.398} & \multirow{4}{*}{0.094} \\
\hline & Vocational school & 24 & 64.48 & & \\
\hline & University & 69 & 64.80 & & \\
\hline & Graduate - PHD & 19 & 88.39 & & \\
\hline \multirow{4}{*}{$\begin{array}{l}\text { I see the e-government system as a system to } \\
\text { facilitate bureaucratic operations }\end{array}$} & High school and under & 23 & 48.61 & \multirow{4}{*}{7.368} & \multirow{4}{*}{0.061} \\
\hline & Vocational school & 24 & 72.96 & & \\
\hline & University & 69 & 71.49 & & \\
\hline & Graduate - PHD & 19 & 72.53 & & \\
\hline \multirow{4}{*}{$\begin{array}{l}\text { Through e-government system, I am notified to the } \\
\text { official institutions of desire, complaints and } \\
\text { requests }\end{array}$} & High school and under & 23 & 69.74 & \multirow{4}{*}{1.981} & \multirow{4}{*}{0.576} \\
\hline & Vocational school & 24 & 67.25 & & \\
\hline & University & 69 & 64.90 & & \\
\hline & Graduate - PHD & 19 & 78.11 & & \\
\hline
\end{tabular}

Table 15. Comparison of Educational Status Groups of 1998-2000 in terms of Scale Expression Participation Level

\begin{tabular}{|c|c|c|c|c|c|}
\hline Education Status & & $\mathbf{n}$ & rank average & $\mathbf{X 2}$ & $\mathbf{p}$ \\
\hline \multirow{3}{*}{ Actively use the e-government system } & High school and under & 98 & 64.86 & \multirow{3}{*}{8.001} & \multirow{3}{*}{$0.018 *$} \\
\hline & Vocational school & 24 & 87.17 & & \\
\hline & University & 13 & 56.31 & & \\
\hline \multirow{3}{*}{$\begin{array}{l}\text { I see the e-government system as a system to facilitate } \\
\text { bureaucratic operations }\end{array}$} & High school and under & 98 & 68.06 & \multirow{3}{*}{1.600} & \multirow{3}{*}{0.449} \\
\hline & Vocational school & 24 & 73.63 & & \\
\hline & University & 13 & 57.15 & & \\
\hline \multirow{3}{*}{$\begin{array}{l}\text { Through e-government system, I am notified to the official } \\
\text { institutions of desire, complaints and requests }\end{array}$} & High school and under & 98 & 73.09 & \multirow{3}{*}{7.074} & \multirow{3}{*}{$0.029 *$} \\
\hline & Vocational school & 24 & 54.52 & & \\
\hline & University & 13 & 54.54 & & \\
\hline
\end{tabular}

In Table 13, there is a comparative test in terms of scores of participation levels among the educational status groups according to generation groups. According to Kruskal Wallis test for educational status groups in different generation groups; there is a statistically significant difference $(1 / 425.732, p<0.05)$ in terms of participation level in the expression of "actively use of e-government system" among educational status groups between 1960-1977. The average score of primary school graduates is $35.68,59.10$ for middle school graduates, 63.47 for high school graduates, 80.59 for college graduates, 81.83 for university graduates and 89.13 for graduate and doctoral graduates. According to this, graduates of masters and doctorates have a higher level of participation in the expression. 
Table 16. Comparison of having an e-government cipher in terms of scale expressions participation level

\begin{tabular}{|c|c|c|c|c|c|c|}
\hline Generation & $\begin{array}{l}\text { Do you have } \\
\text { e-government encryption? }\end{array}$ & & $\mathbf{n}$ & Rank average & $\mathbf{U}$ & $\mathbf{p}$ \\
\hline \multirow{6}{*}{$1960-1977$} & \multirow{2}{*}{$\begin{array}{l}\text { I see the e-government system as a system to facilitate } \\
\text { bureaucratic operations }\end{array}$} & Yes & 111 & 68.55 & \multirow{2}{*}{1271.0} & \multirow{2}{*}{0.718} \\
\hline & & No & 24 & 65.46 & & \\
\hline & \multirow{2}{*}{ Actively use the e-government system } & Yes & 111 & 75.63 & \multirow{2}{*}{485.0} & \multirow{2}{*}{$0.000 *$} \\
\hline & & No & 24 & 32.71 & & \\
\hline & \multirow{2}{*}{$\begin{array}{l}\text { Through e-government system, I am notified to the } \\
\text { official institutions of desire, complaints and requests }\end{array}$} & Yes & 111 & 69.37 & \multirow{2}{*}{1179.5} & \multirow{2}{*}{0.367} \\
\hline & & No & 24 & 61.65 & & \\
\hline \multirow{6}{*}{ 1978-1997 } & \multirow{2}{*}{$\begin{array}{l}\text { I see the e-government system as a system to facilitate } \\
\text { bureaucratic operations }\end{array}$} & Yes & 124 & 67.81 & \multirow{2}{*}{659.0} & \multirow{2}{*}{0.848} \\
\hline & & No & 11 & 70.09 & & \\
\hline & \multirow{2}{*}{ Actively use the e-government system } & Yes & 124 & 71.98 & \multirow{2}{*}{189.0} & \multirow{2}{*}{$0.000 *$} \\
\hline & & No & 11 & 23.18 & & \\
\hline & \multirow{2}{*}{$\begin{array}{l}\text { Through e-government system, I am notified to the } \\
\text { official institutions of desire, complaints and requests }\end{array}$} & Yes & 124 & 68.31 & \multirow{2}{*}{644.0} & \multirow{2}{*}{0.745} \\
\hline & & No & 11 & 64.55 & & \\
\hline \multirow{6}{*}{$1998-2000$} & \multirow{2}{*}{$\begin{array}{l}\text { I see the e-government system as a system to facilitate } \\
\text { bureaucratic operations }\end{array}$} & Yes & 98 & 69.67 & \multirow{2}{*}{1649.5} & \multirow{2}{*}{0.404} \\
\hline & & No & 37 & 63.58 & & \\
\hline & \multirow{2}{*}{ Actively use the e-government system } & Yes & 98 & 83.62 & \multirow{2}{*}{282.0} & \multirow{2}{*}{$0.000 *$} \\
\hline & & No & 37 & 26.62 & & \\
\hline & \multirow{2}{*}{$\begin{array}{l}\text { Through e-government system, I am notified to the } \\
\text { official institutions of desire, complaints and requests }\end{array}$} & Yes & 98 & 64.65 & \multirow{2}{*}{1484.5} & \multirow{2}{*}{0.080} \\
\hline & & No & 37 & 76.88 & & \\
\hline
\end{tabular}

${ }^{\star} p<0.05$ there is a significant difference; $p>0.05$ no significant difference

In Table 15, there is a comparative test in terms of scores of participation levels among the educational status groups according to generation groups. There is a statistically significant difference between the groups of education status in the $1998-2000$ period $(-7.074, p<0.05)$ in terms of the level of involvement in the expression of "complaint and request to notify official institutions via e-government services". The average score of high school and six graduates is $73.09,54.52$ for associate degree graduates and 54.54 for university graduates. According to this, those who have high school and six graduates have a higher level of participation in the expression.

In Table 16, there is a comparative test in terms of scale expressions participation level scores between having an e-government cipher according to generation groups. According to Mann Whitney test for egovernment password in different generation groups; there is a statistically significant difference in the level of participation level in the phrase "actively use of the e-government services" between the 1960-1977 levels of e-government cipher $(U=485.0, p<0.05)$. The average score of those who actively use the e-government system is 75.63 , and those who do not use it actively are 32.71. According to this, those who actively use the e-government system have a higher level of participation in the expression.

There is a statistically significant difference between the 1978-1997 levels of e-state passwords $(U=189.0$, $p<0.05$ ) in terms of participation level in the expression "actively use of e-government services". Those who actively use the e-government system have a score of 71.98 points, and those who do not actively use it are 23.18. According to this, those who actively use the e-government system have a higher level of participation in the expression.

There is a statistically significant difference in terms of participation level score in the expression of "actively use of e-government services" between the 1998-2000 level of e-state passwords $(U=282.0, p<0.05)$. The average score of those who actively use the e-government system is 83.62 , and those who do not actively use the system are 26.62. According to this, those who actively use the e-government system have a higher level of participation in the expression.

\section{CONCLUSION}

Information society and e-government applications transformed the way citizens are interacting with the government and its services. Today, as a part of information society, the development of communication technologies and the widespread use of these technologies is converting our traditional understanding of governmental services. Individuals within these e-governmental services are able to track bureaucratic tasks and make transactions faster in their daily lives. The research of this study was carried out on the perception of e-government services with a questionnaire applied to the $X, Y, Z$ generations to measure the similarities 
Table 17. The characteristics of different generations in terms of e-government services usage

\begin{tabular}{|c|c|}
\hline $\begin{array}{l}\text { Pre-techno } \\
\text { individual }\end{array}$ & $\begin{array}{l}\text { - The usage of e-government services is more active than post-techno individuals. Second rank in terms of active } \\
\text { usage. } \\
\text { - The lowest rate of seeing the e-government services as a system facilitating bureaucratic work. }\end{array}$ \\
\hline $\begin{array}{l}\text { echno } \\
\text { idividual }\end{array}$ & $\begin{array}{l}\text { - The most active users of e-government services. } \\
\text { - The rate of seeing the e-government services as facilitator in bureaucratic work is higher than the others. }\end{array}$ \\
\hline $\begin{array}{l}\text { ost-techno } \\
\text { idividual }\end{array}$ & $\begin{array}{l}\text { - The lowest group with active use of e-government services. } \\
\text { - The level of seeing the e-government services facilitating bureaucratic operations is moderate. } \\
\text { - The lowest level of reporting complaints and requests to government agencies via the e-government system. }\end{array}$ \\
\hline
\end{tabular}

and differences in their understanding of these services. According to this study on generations, three types of individuals was revealed. These individuals are classified according to their age groups and characteristics. The relationship between technology and the development process of technology, the pre-techno individual is born before Internet technology and come across with these technologies after certain age. The techno individual is partnered with Internet technology in a timely manner and use Internet technology during the childhood and youth and also able to capture and actively use this technology in many areas of social life. Finally, a post-techno individual is born after the development of Internet technology or even after its widespread use.

Digital culture has the power reshape the social life and the citizens from different generations, even unconsciously, are going through the effects of this newly constructed social life. For example, the use of egovernment portal in pre-techno individuals is more common than post-techno individuals since bureaucratic procedures must be carried out through this system, pre-techno group uses it more often. Contrary to the expected, post-technological individuals are less digital than techno individuals. The reason for this situation is that this age group does not need to use governmental services as much as the others. In this case, technoindividuals are the most affected generation as these individuals grow up with technology, they have been subjected to all reflections of digital culture.

According to the results of the research, the findings about the perception of e-government services amongst different generations could be summarized as Table 17.

The typology constructed from the research yet has to be improved by involving different perception aspects of the digital life such as online shopping and online gaming. This study might be considered as a starting point for future researches. The differences between generations' understanding of digital life and culture can be analyzed from point of views of other countries' citizens. This might be beneficial to reveal the connection between digital cultures, generation cultures and socio cultural aspects of governments.

\section{REFERENCES}

Agostino, D., \& Arnaboldi, M. (2016). A Measurement Framework for Assessing the Contribution of Social Media to Public Engagement: An empirical analysis on Facebook. Public Management Review, 18(9), 12891307. https://doi.org/10.1080/14719037.2015.1100320

Alshehri, M., \& Drew, S. (2010). Implementation of e-government: advantages and challenges. International association for scientific knowledge (IASK) E-ALT Conference proceedings, 79-86.

E-Government in Turkey, Joinup Europa (February 2016). Retrieved from https://joinup.ec.europa.eu

Firmstone, J., \& Coleman, S. (2015). Public engagement in local government: the voice and influence of citizens in online communicative spaces, Information. Communication \& Society, 18(6), 680-695. https://doi.org/10.1080/1369118X.2014.986180

Freeman, J., \& Quirke, S. (2013). Understanding E-Democracy Government-Led Initiatives for Democratic Reform. JeDEM, 5(2), 141-154. https://doi.org/10.29379/jedem.v5i2.221

Haider, Z., Shuwen, C., \& Hyder, S. (2014). Citizens' participation in e-government services: A Comparative Study of Pakistan \& Singapore. Journal of Electronics and Communication Engineering, 9(6), 35-48. https://doi.org/10.9790/2834-09613548

Haller, M., Li, M.-H., \& Mossberger, K. (2011). Does e-government use contribute to citizen engagement with government and community? APSA 2011 Annual Meeting. Rochester, NY: Social Science Research Network. 
Holzer, M., \& Manoharan, A. P. (n.d.). Digital Governance in Municipalities Worldwide 2015- 2016 - Longitudinal Assessment of Municipal Websites throughout the World. Rutgers University.

infoDev/World Bank, "e-Government Primer", Washington, DC; infoDev/World Bank. (2009). Retrieved from http://www.infodev.org/publications

Kang, S., \& Gearhart, S. (2010). E-Government and Civic Engagement: How is Citizens' Use of City Web Sites Related with Civic Involvement and Political Behaviors? Journal of Broadcasting \& Electronic Media, 54(3), 443-462. https://doi.org/10.1080/08838151.2010.498847

Lidén, G., \& Larsson, A. O. (2016). From 1.0 to 2.0: Swedish municipalities online. Journal of Information Technology \& Politics, 13(4), 339-351. https://doi.org/10.1080/19331681.2016.1169242

Merrienboer, J. V., \& Driscoll, M. P. (Eds.). (2007). Handbook of research on educational Organisation for Economic and Co-operation and Development (OECD). Citizens as Partners - OECD Handbook on Information, Consultation and Public Participation in Policy Making walks through some of the elements that need to be considered when building a framework. Retrieved from www.oecdbookshop.org

Partnership on Measuring ICT for Development and the United Nations Economic Commission for Africa (2012). Framework for a set of e-government core indicators. Retrieved from http://www.uneca.org/ publications/framework-set-e-government-core-indicators

Partnership on Measuring ICT for Development and the United Nations Economic Commission for Africa. (2012). Framework for a set of e-government core indicators. Available from http://www.uneca.org/ publications/framework-set-e-government-core-indicators

Pew Research Center, A Portrait of Generation Next. (2010). Retrieved from http://www.pewsocialtrends.org/files/2010/10/millennials-confident-connected-open-to-change.pdf

Reeves, T., \& Oh, E. (2007). Generational differences. In J.M. Spector, M.D. Merrill, J. van

Sæbø, Ø., Rose, J., \& Skiftenes Flak, L. (2008). The shape of eParticipation: Characterizing an emerging research area. Government Information Quarterly 25(3), 400-428. https://doi.org/10.1016/j.giq.2007.04.007

Suh, S. Y. (2005). Promoting Citizen Participation in e-Government <From the Korean Experience in e-Participation>. Retrieved from http://unpan1.un.org/intradoc/groups/public/documents/un/unpan020076.pdf

Trechsel, A., Kies, R., Mendez, F., \& Schmitter, P. (2003). Evaluation of the Use of New Technologies in Order to Facilitate Democracy in Europe. Strasbourg, European Parliament, STOA.

Turkish Statistical Institute Report. (2017) Retrieved from http://www.tuik.gov.tr/HbGetirHTML.do?id=24638

Turkish Statistical Institute, August 2017

Turkish Statistical Institute, Press Release, August 2016.

Turkish Statistical Institute. (2017). Information and Communication Technology (ICT) Usage Survey on Households and Individuals, 2017. Retrieved from http://www.turkstat.gov.tr/PreHaberBultenleri.do?id=24862

United Nations, Department of Economic and Social Affairs. Global E-government Readiness Report 2004: Toward Access for Opportunity. (2004). Retrieved from http://unpan1.un.org/intradoc/groups/public/ documents/un/unpan019207.pdf

UNPAN. (2016). UN e-Government Survey 2016. E-Government in Support of Sustainable Development. New York: UNPAN.

World Values Survey. (n.d.). Retrieved from http://www.worldvaluessurvey.org/WVSOnline.jsp

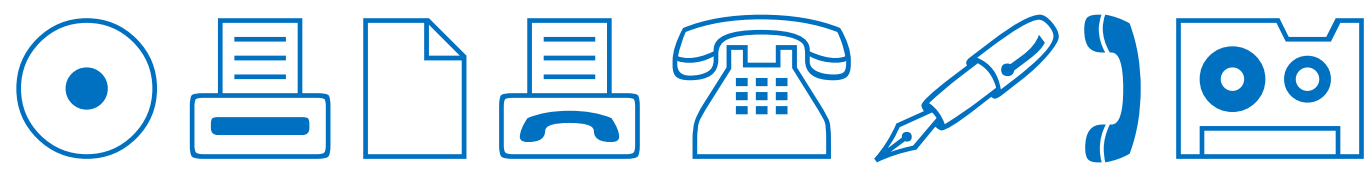

